\title{
Contrasting the Indian and East Asian monsoons: implications on geologic timescales
}

\author{
Bin Wang ${ }^{\mathrm{a}, \mathrm{b}, *}$, Steven C. Clemens ${ }^{\mathrm{c}}$, Ping Liu ${ }^{\mathrm{b}, 1}$ \\ a Department of Meteorology, University of Hawaii, Honolulu, HI, USA \\ b International Pacific Research Center, School of Ocean Earth Science and Technology, University of Hawaii, Honolulu, HI, USA \\ c Department of Geological Sciences, Brown University, Providence, RI, USA
}

Accepted 19 June 2003

\begin{abstract}
The surface winds over the Arabian Sea and South China Sea are meaningful indicators for the strength of the Indian monsoon and East Asian monsoon, respectively. Paleo-monsoon variability has been studied through analysis of sediment records from these two monsoon regions. To facilitate interpretation of these records, we focus on the impacts of 'internal' and 'external' forcing of the monsoon system by contrasting the annual cycle and interannual variability of two subsystems: the monsoon over the Indian sector $\left(40-105^{\circ} \mathrm{E}\right)$ and over the East Asian sector (105$160^{\circ} \mathrm{E}$ ). Differences in the annual cycle within these subsystems arise primarily from the different land-ocean configurations that determines atmospheric response to the solar forcing. Thus factors that drive intensities of the monsoonal annual cycle share common features with the external (geographic and orbital) forcing that controls paleomonsoon variability. We show that the differences in interannual variations between the two monsoon subsystems are primarily due to internal factors of the coupled atmosphere-ocean-land system, such as remote impacts of El Niño/La Niña and local monsoon-ocean interactions. The mechanisms that operate on interannual to interdecadal timescales may differ fundamentally from that on geologic/orbital timescales. The low-level flows over the East Asia and Australia are essentially established by geographic forcing. The amplification of the Australia summer monsoon during increased solar precession is likely caused by an enhanced East Asian winter monsoon, rather than following an enhanced Indian summer monsoon as on the interannual timescale. It is also found that El Niño influences the low-level flow moderately over the Arabian Sea but to a greater extent over the South China Sea. As such, large changes in the Pacific thermal conditions may significantly alter the intensity of the East Asian monsoon but not the Indian monsoon.
\end{abstract}

(C) 2003 Elsevier B.V. All rights reserved.

Keywords: Indian monsoon; East Asian-Australian monsoon; geographic forcing; orbital forcing; monsoon-ocean interaction; ENSO forcing

\footnotetext{
1 Also affiliated with LASG/Institute of Atmospheric Physics, Chinese Academy of Sciences, Beijing, China, 100029. The International Pacific Research Center is sponsored in part by the Frontier Research System for Global Change.

* Corresponding author. Present address: International Pacific Research Center, University of Hawaii, Honolulu HI, 96822. Fax: 1-808-956-9425.

E-mail address: wangbin@hawaii.edu (B. Wang).
} 


\section{Introduction}

Paleo-monsoon studies have advanced through the study of sediment records on the ocean floor in the Arabian Sea and South China Sea (Clemens and Prell, 1990; Clemens et al., 1996; Clemens et al., 1991; Overpeck et al., 1996; Prell et al., 1992; Schulz et al., 1998; Shimmield et al., 1990; Sirocko, 1991; Wang et al., 1999; Wang, 1999). Changes in sediment deposits in these regions reflect the influence of the summer- and wintermonsoon winds and precipitation on the physical, chemical, biotic, and isotopic characteristics of ocean surface and deep waters. On the annual timescale the strongest seasonal reversal of winds between January/February and July/August occurs over the western Arabian Sea with a secondary maximum over the South China Sea (Figs. 1 and 4). Since the wind and precipitation variations in these two regions are good indicators of the intensity of the Indian and East Asian monsoons, the sediment changes to large extent reflect variations in these monsoons.

The classical view of monsoons contemplates the land/sea thermal contrast and annual cycle of solar radiation as fundamental factors that establish monsoons. On geologic timescales the tectonic forcing shapes the land-ocean distribution and controls the formation of the Asian-Australian monsoon (A-AM hereafter) system. On the Milankovitch timescale changes in solar orbit parameters (the obliquity or tilt of the Earth's rotational axis, the date of perihelion and the eccentricity of the Earth's orbit) induce large-amplitude monsoon variability (e.g. Kutzbach and Guetter, 1984). Interannual and decadal monsoon variations are mainly caused by physical processes internal to the earth's climate system such as El Niño-Southern Oscillation (ENSO) and local atmosphere-ocean-land interaction. Understanding mechanisms driving monsoon variability requires bringing together information gained from investigation of both instrumental and proxy data.

The most pronounced annual reversal in atmospheric circulation and precipitation on the Earth is located in the tropical region from $40^{\circ} \mathrm{E}$ to $160^{\circ} \mathrm{E}$ and from $30^{\circ} \mathrm{S}$ to $45^{\circ} \mathrm{N}$ (Ramage, 1971 ; Krishnamurti et al., 1985; Wang, 1994; Webster et al., 1998; Trenberth et al., 2000), which is referred to as A-AM domain (Fig. 1). From the monsoon climate point of view the line of $105^{\circ} \mathrm{E}$ longitude, which runs along the eastern flank of the Tibetan Plateau and through the Indo-China 'land bridge', delineates the Indian monsoon and East Asia-western North Pacific (WNP) monsoon regions (Wang and Lin, 2002). In the Southern Hemisphere the $105^{\circ} \mathrm{E}$ longitude separates roughly the maritime continent and the Australian landmass from the Indian Ocean. The contrasting land/ocean configuration to its east and west is believed to have a rudimentary impact on the monsoon climate over India and East Asia. On the interannual timescale the variations of the monsoon over the areas around India and that over the East Asia-WNP sector (for brevity it will be referred to as East Asian sector hereafter) exhibit strikingly different spatial and temporal structures (Wang et al., 2001). It is important to understand how the annual cycle in these two regional subsystems differs and, in particular, what these differences imply for understanding of the paleo-monsoon variability. Careful analyses of such differences may shed light on the interpretation of the paleo-monsoon records collected in the Arabian Sea and South China Sea.

The South China Sea is intimately connected with the WNP warm pool and the local atmospheric general circulation is significantly influenced by ENSO. Changes of the monsoon intensity induced by the factors internal to the coupled atmosphere-ocean-land system such as ENSO would distort an accurate estimation of those caused by the external geographic or orbital forcing. Thus, in order to more precisely interpret the paleo-monsoon variability based upon the sediment records under the South China Sea, it is critical to know how much the East Asian monsoon is affected by changes in Pacific thermal conditions. This study is intended to investigate the nature of internal forcing and its impact on the wind indicators over the Arabian Sea and South China Sea.

Clemens and Kershaw (pers. commun.) find that the phase of the summer-monsoons pollen records (three marine cores off northern Australia) matches the summer-monsoon phase mea- 
sured in sediment cores from the northern Arabian Sea (the Indian monsoon). In other words, on orbital timescale, enhanced Indian summer monsoons are 'in phase' with enhanced Australian summer monsoons. On the ENSO timescale, a strong Indian summer monsoon is also followed by a strong Australian summer monsoon (Meehl, 1987). Are these similar in-phase relationships caused by similar mechanisms? Is the orbital-scale variability in the Australian summer monsoon related to the changes in the Indian summer monsoon? Clarifying these complex relationships requires realistic simulations of the interactions between the A-AM and ENSO and among the A-AM subsystems with coupled atmosphereocean models. Unfortunately the state-of-the-art coupled atmosphere-ocean general circulation models (CGCMs) cannot faithfully reproduce variations associated with such interactions. Most of 23 coupled models participating the coupled model intercomparison project (Meehl et al., 2000) have difficulty in reproducing the observed annual mean equatorial sea surface temperature (SST) and wind stress as well as the Indian-Pacific lag correlation (Davey et al., 2002). Few models have realistically simulated the ENSO with respect to equatorial SST anomalies (Latif et al., 2001). Also because large ensemble simulations are necessary to reasonably simulate the monsoon-ENSO interaction, it is extremely difficult to address this open issue based upon the present-day CGCMs.

Asian subsystems are driven by different boundary thermal conditions associated with land-ocean configuration and topography, investigation of their different characteristics over annual cycle may enhance our understanding how tectonic and solar orbital forcing affects paleomonsoon variation. Likewise study of different responses and feedbacks of these monsoon subsystems to ENSO and warm pool conditions may shed light on how internal dynamics of the coupled atmosphere-ocean system influences the monsoon interannual variability.

There is a rich source of literature describing annual variations of rainfall in these two monsoon regions. The focus of this study is the longitudinal distinction in both annual cycles and interannual variations with particular attention paid to the differences between the Indian $\left(40-105^{\circ} \mathrm{E}\right)$ and East Asian $\left(105-160^{\circ} \mathrm{E}\right)$ sectors.

We first document the contrasting features in their annual cycles (Section 3) and interannual variations associated with ENSO (Section 4). We then discuss mechanisms accounting for such differences (Section 5). Section 6 presents a summary of major results and further discusses the implications for interpreting paleo-monsoon variability.

\section{Data and analysis methods}

The National Centers for Environmental Prediction-National Center for Atmospheric Research (NCEP-NCAR) Reanalysis (Kalnay et al., 1996) provides the atmospheric data for the period of 1951-2000. Our analysis will focus on boundary layer winds at $925 \mathrm{hPa}$ and precipitation. These data are on regular grids with a horizontal resolution of $2.5^{\circ} \times 2.5^{\circ}$. The SST data are obtained from the Reynolds SST (Reynolds and Smith, 1994) in the NCEP-NCAR Reanalysis. Monthly mean precipitation data derived from the Climate Prediction Center Merged Analysis of Precipitation (CMAP; Xie and Arkin, 1997) data (January 1979-December 2000) were used for describing the annual cycle of precipitation and to check the quality of the Reanalysis precipitation anomalies. It was found that the largescale patterns of monthly mean precipitation anomalies derived from Reanalysis rainfall and CMAP are in a reasonably good agreement, which enables us to make a meaningful analysis of A-AM anomalies for the extended period from 1951 to 2000.

Previous studies have been largely concerned with regional monsoon variability, rather than the entire Asian-Australian monsoon system. There are enormous regional differences among the two subsystems. The Indian summer monsoon rainfall was found to be deficient in an El Niño developing year (see review by Webster et al., 1998), although this relation broke down in the last two decades (Kumar et al., 1999). Deficient rainfall over Australian monsoon region occurs during northern fall and winter, often following 


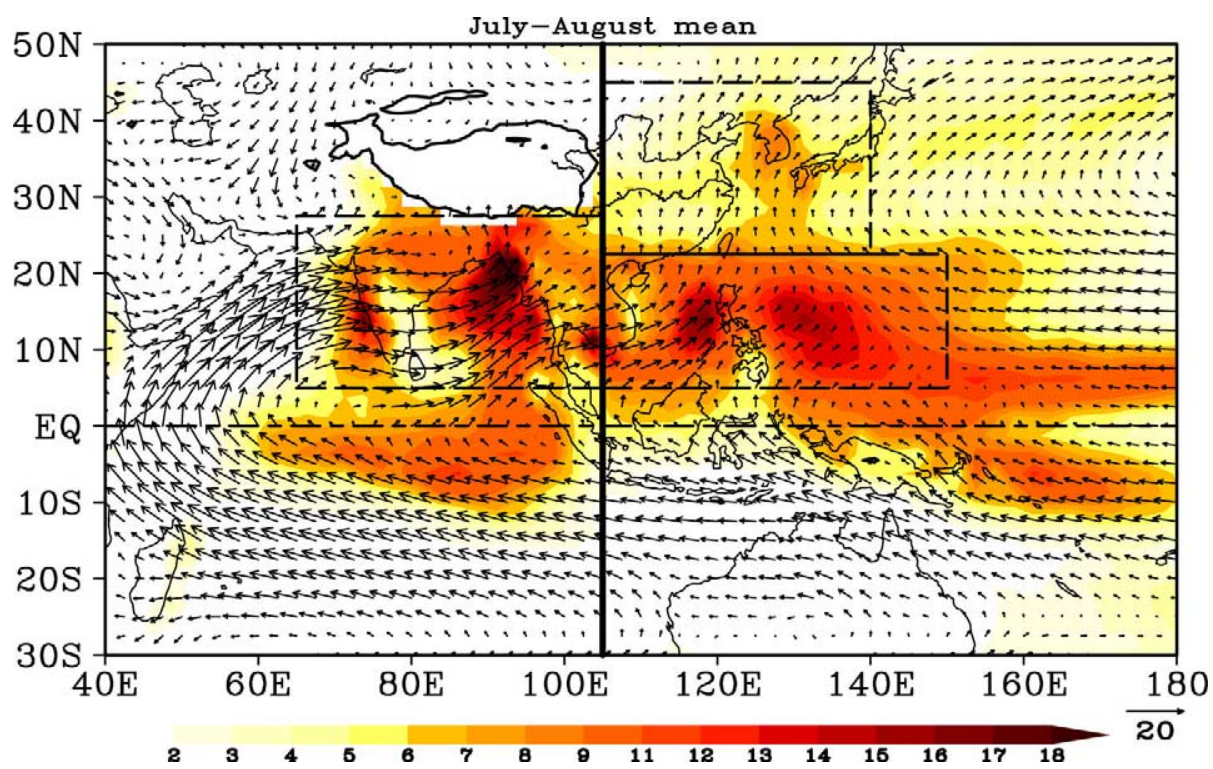

Fig. 1. Climatological July-August mean precipitation rates (shading in mm/day) and $925 \mathrm{hPa}$ wind vectors (arrows) in the AAM region. The precipitation and wind climatology are derived from CMAP (Xie and Arkin, 1997) (1979-2000) and NCEP/ NCAR reanalysis (1951-2000), respectively. The three boxes define major summer precipitation areas of the Indian tropical monsoon $\left(5-27.5^{\circ} \mathrm{N}, 65-105^{\circ} \mathrm{E}\right)$, WNP tropical monsoon $\left(5-22.5^{\circ} \mathrm{N}, 105-150^{\circ} \mathrm{E}\right)$, and the East Asian subtropical monsoon $(22.5-$ $\left.45^{\circ} \mathrm{N}, 105-140^{\circ} \mathrm{E}\right)$.

a deficient Indian monsoon (Meehl, 1987). In contrast to the Indian monsoon, the summer monsoon in East Asia and WNP tends to be more affected during the year after the El Niño mature phase. Due to the strong season-dependence and ENSO phase-dependence of the A-AM anomalies, we introduced a composite technique to document the common features of evolving anomalies of the A-AM system. This approach is distinguished from the previous analyses in that it focuses on finding a sequence of variability patterns that are associated with the evolution of ENSO. The composite scenario presented in this paper will better reveal the ENSO phase-dependent seasonal mean anomalies of the entire AAM anomalies, thus providing a new perspective of the A-AM anomalies associated with a switch from developing to decaying phases of ENSO. This facilitates understanding of the A-AM variability due to forcing internal to the coupled climate system.

\section{The contrasting annual cycles in the Indian and East Asia sectors}

The summer monsoon in the Indian and East Asia sectors exhibits different spatial structures (Fig. 1). The Indian monsoon system is dominated by a distinct clockwise monsoon gyre centered in the equatorial Indian Ocean, which ties the Indian monsoon trough, Somalia jet and southeast winds associated with Mascarene High (Fig. 1; Krishnamurti and Bhalme, 1976). In contrast, the East Asia sector monsoon consists of three circulation components: (a) the WNP monsoon trough (also known as the intertropical convergence zone) that is the confluence zone between the southwesterly monsoon and southeast winds which originate from the Pacific trades, (b) the massive WNP subtropical ridge which is located to the north of the monsoon trough with its edge extending to the coastal area of East Asia; and (c) the East Asian subtropical front (Meiyu front) 
CMAP longterm mean pentad variation (a) $65^{\circ} \mathrm{E} \sim 105^{\circ} \mathrm{E}$ mean

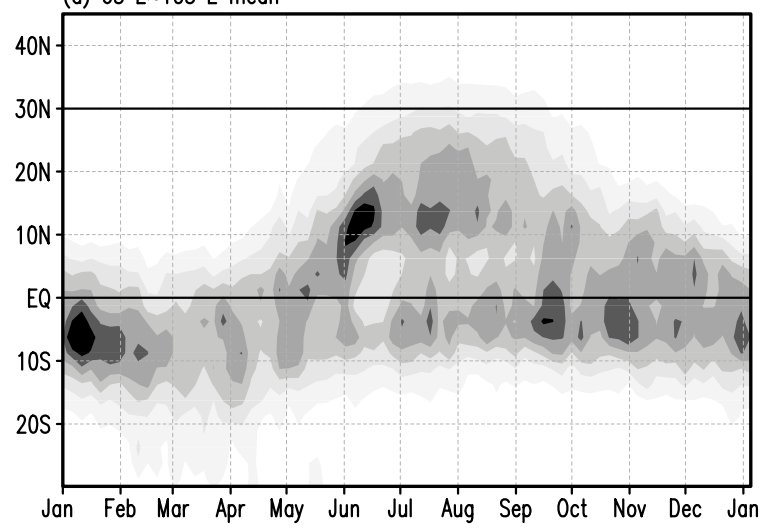

(b) $105^{\circ} \mathrm{E} \sim 145^{\circ} \mathrm{E}$ mean
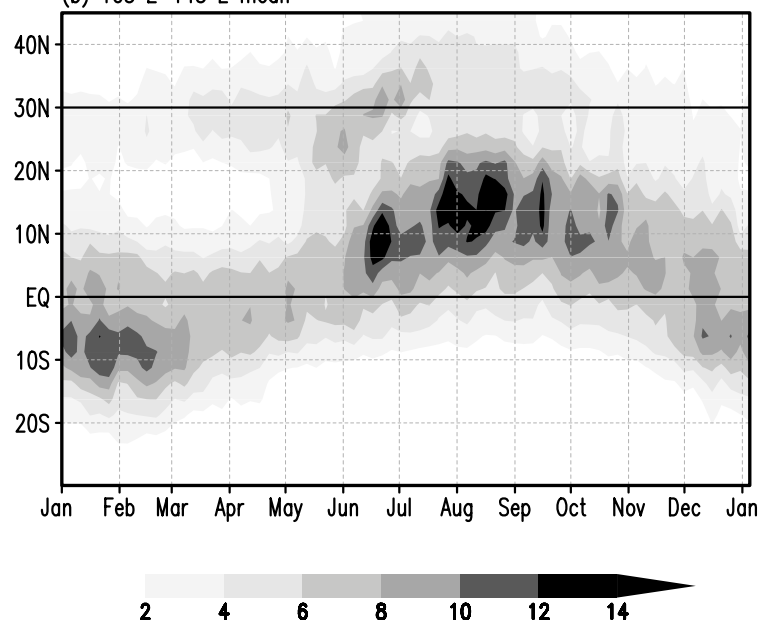

Fig. 2. Climatological pentad (5-day) mean precipitation rate (mm/day) averaged over (a) the Indian sector $\left(65-105^{\circ} \mathrm{E}\right)$, and (b) the western Pacific sector $\left(105-145^{\circ} \mathrm{E}\right)$. The data used are derived from CMAP (Xie and Arkin, 1997) for the period of 1979-2000.

(Tao and Chen, 1987). The term 'Meiyu' means 'plum rain' which normally occurs from mid-June to mid-July when the East Asian subtropical monsoon front stagnates in a narrow zone extending from the Yangtze River valley to southern Japan. Japanese called it Baiu and Koreans called it Changma. The term 'Meiyu', 'Baiu', and Changma' all mean the same East Asian subtropical rain band that brings a major summer rainy period to these countries. In Fig. 1, the subtropical front is weak, because the major subtropical front rainfall occurs before early July, thus does not show up well in the July-August mean field. A clearer picture of the subtropical front and associated precipitation can be identified from the north-south cross-section shown in Fig. 2b. The East Asia subtropical rain band occurs from midMay to early July and migrates northward from $20^{\circ} \mathrm{N}$ to $35^{\circ} \mathrm{N}$. In between the subtropical and tropical monsoon rain is a relatively dry zone, which signifies the location of subtropical ridge (Figs. 1 and 2b).

The central monsoon system in the East Asia sector is the WNP monsoon trough and associated heavy rainfall (Fig. 1). It is important to realize that the WNP rainfall and associated latent heat release is stronger than that over the Indian monsoon region. As shown in Fig. 1, two areas are chosen to represent the Indian monsoon $\left(5-27.5^{\circ} \mathrm{N}, 65^{\circ} \mathrm{E}-105^{\circ} \mathrm{E}\right)$ and WNP monsoon $\left(5-22.5^{\circ} \mathrm{N}, 105-150^{\circ} \mathrm{E}\right)$, respectively. The sizes of the two rectangular areas are almost even, yet the mean precipitation rate in May-October is 8.61 $\mathrm{mm}$ /day over the WNP monsoon region while only about $6 \mathrm{~mm} /$ day over the Indian monsoon region (Fig. 3). The strong WNP latent heat source is dynamically consistent with the upperlevel divergent circulation center near the Philippines as first revealed by Krishnamurti (1971) and recently confirmed by Trenberth et al. (2000).

Note that the immense WNP heat source is connected not only with the Indian monsoon but also directly linked with Australian winter monsoon trough and the pronounced low-level northward cross-equatorial flows over the South China Sea, Celebes, and the northeastern part of New Guinea (Fig. 1; also see Tao and Chen, 1987; Wang and Lin, 2002). The cross-equatorial clockwise gyre in the East Asia sector is not as strong as that over the Indian sector, yet it does suggest that the cold Australian land surface enhances the hemispheric thermal contrast and contributes to the moisture convergence over the WNP summer monsoon. To the north, the WNP heat source is coupled with the WNP subtropical ridge and the East Asia subtropical monsoon. The coupling between the tropical WNP monsoon and the subtropical monsoon is particularly evidenced by their in-phase sub-seasonal variations in June and July (Fig. 3). At pentad 


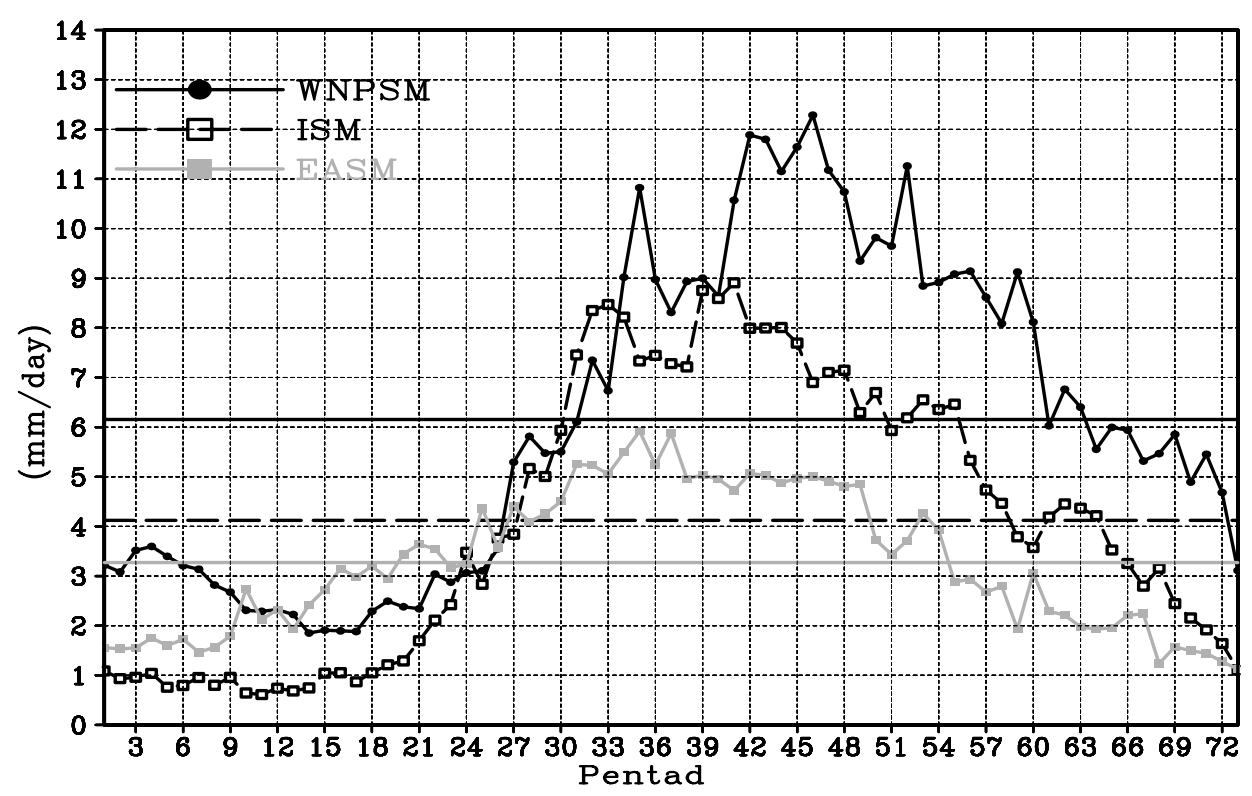

Fig. 3. Climatological pentad mean precipitation rate $\left(\mathrm{mm} /\right.$ day) averaged over three regions: Indian summer monsoon $\left(5-27.5^{\circ} \mathrm{N}\right.$, $\left.65-105^{\circ} \mathrm{E}\right)$, WNP summer monsoon $\left(5-22.5^{\circ} \mathrm{N}, 105-150^{\circ} \mathrm{E}\right)$, and East Asian summer monsoon $\left(22.5-45^{\circ} \mathrm{N}, 105-140^{\circ} \mathrm{E}\right)$. The abscissa runs from pentad 1 (January 1-5) to pentad 73 (December 27-31). The data used are derived from CMAP (Xie and Arkin, 1997) for the period of 1979-2000. The thick, thin, and long-dashed horizontal lines indicate, respectively, the annual mean rainfall rates averaged for the WNP, East Asian, and Indian monsoon regions.

35 (June 20-24), the wet spell in the WNP (onset in the southwest Philippine Sea) concurs with the maximum East Asia rainfall (peak Meiyu). The dry singularity in the WNP at pentad 49 (end of August) is directly followed by the retreat of East Asia rainy season (the sudden decrease of the monsoon rainfall at pentad 50). The pronounced sub-seasonal variations of the WNP summer monsoon were termed the climatological intraseasonal oscillation (CISO) that arises from phase locking of transient intraseasonal oscillations by the annual cycle (Wang and $\mathrm{Xu}, 1997$ ).

The temporal evolutions of the monsoon subsystems over the Indian and East Asian sectors are also different. The Indian rainy season reaches peaks in early June and mid-July (Fig. 2a) with maximum rainfall occurring in early June and the corresponding rain band reaches the northernmost latitude $\left(\sim 25^{\circ} \mathrm{N}\right)$ in mid-July. On the other hand, over the East Asia sector, both the maximum intensity and the northernmost location $\left(\sim 25^{\circ} \mathrm{N}\right)$ of the tropical monsoon rain are found in August (Fig. 2b), which matches the peaks rainfall in mid-August shown in Fig. 3. This phase difference in the annual cycle implies an eastward shift of convection centers from India (in June-July) to the WNP (in August) during boreal summer. Accordingly, the Indian rainy season ends in late-September, while the WP rainy season retreats in late October (Fig. 3).

Another prominent difference is that over the Indian sector, the summer rainfall is characterized by double rain bands, one is located about $15^{\circ} \mathrm{N}$ and the other at $5^{\circ} \mathrm{S}$, whereas over the East Asian sector, only a single tropical monsoon rain band is located north of the equator from June to October. However, from late May to mid-July, a northward migration of the Meiyu from $20^{\circ} \mathrm{N}$ to $35^{\circ} \mathrm{N}$ can be clearly seen. This subtropical monsoon rain belt is produced downstream of the Tibetan Plateau, which prohibits such a rain band formation over the Indian sector. Thus the Indian tropical monsoon rain has a close link with the equatorial convections throughout the entire summer, whereas the monsoon rain in the tropical WP monsoon has close linkage with the subtropical monsoon rain in early summer.

While the Indian summer monsoon is stronger 


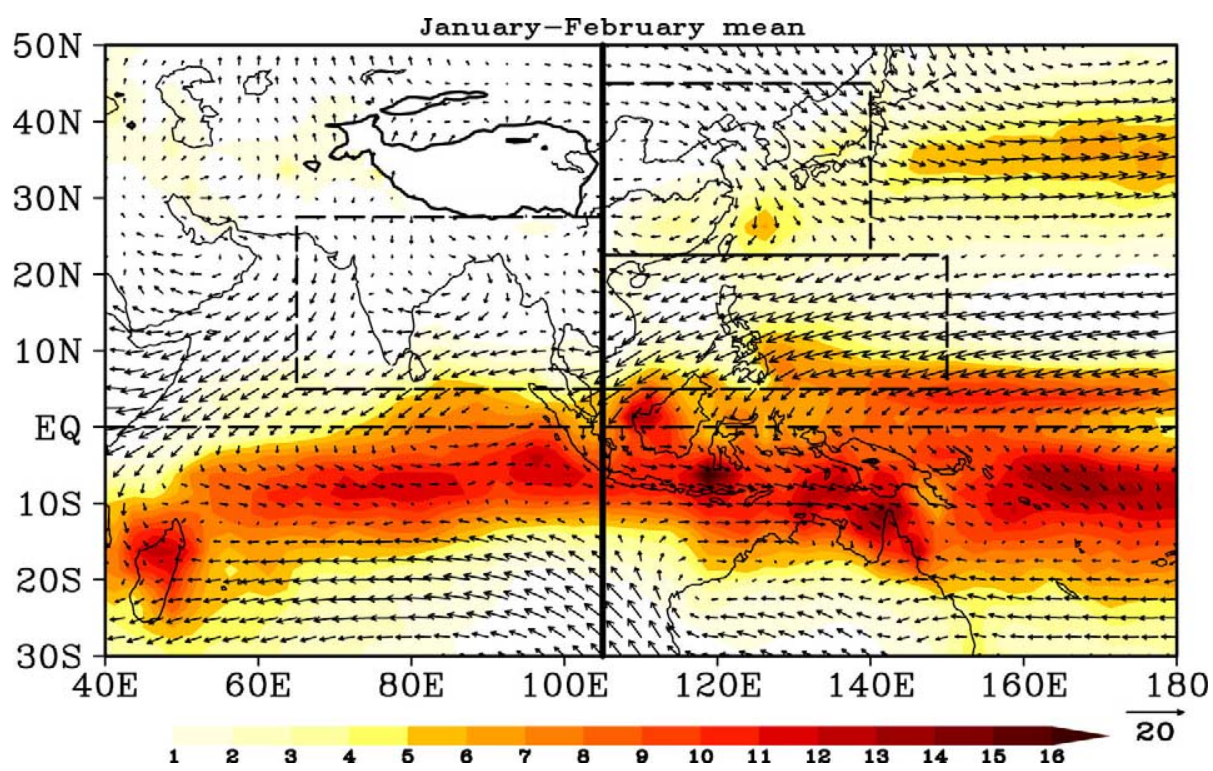

Fig. 4. Same as in Fig. 1 except for January-February mean.

than the monsoon in East Asian sector (Fig. 1), the East Asian winter monsoon is much stronger than Indian winter monsoon (Fig. 4). In January and February, the most powerful winter monsoon occurs over East Asia and adjacent marginal seas. This powerful winter monsoon is directly linked to Australian summer monsoon westerly through marked cross-equatorial flows over the South China Sea and Celebes (Fig. 4), confirming that the annual cycle of the Australian monsoon has a firmer link to East Asian monsoon than to Indian monsoon. Consistent with the monsoon circulation, the rainfall in the Australian sector is more intense than that in the South Indian Ocean convergence zone (Fig. 4). Thus, the active convection and rainfall region shifts from Indian sector in boreal summer to the East Asian sector in austral summer.

\section{Differences in interannual variability between Indian and East Asian monsoons}

On the interannual timescale, the ENSO has been recognized as a major cause of the A-AM variability. In this section, we examine the difference in the monsoon variability between the In- dian and WP sectors. To this end, one has to document the evolving A-AM anomalies associated with ENSO turnabout.

We take boreal winter of the El Niño year as a reference season because the turnabout of ENSO cycle often occurs in boreal winter. As shown in Fig. 5, twelve significant warm episodes (1951, 1957, 1963, 1965, 1968/1969, 1972, 1976, 1982, 1986/1987, 1991, 1994, 1997) occurring during the period of 1951-2000 all matured during October to February except for the episode of 1986/ 1987. During the same period, nine significant cold episodes had occurred (1954/1955, 1964, 1967/1968, 1970, 1973, 1975, 1984, 1988, 1998/ 1999); all reached their peaks in November to February. Based on the strong phase-lock behavior of ENSO cycle, a composite scenario is made with reference to the mature phases of ENSO, $\mathrm{D}(0) / \mathrm{JF}(1)$, where year 0 represents the El Niño developing year and year 1 means the following year. Fig. 6 shows the SST anomaly patterns composite for the 10 El Niño events outlined by the solid boxes in Fig. 5. The double-peak warm events, 1968/1969 and 1986/1987 were excluded, because these events last two years, which is not common to others. The JJA(0), $\mathrm{D}(0) / \mathrm{JF}(1)$, and JJA(1) SST anomalies represent those in the de- 

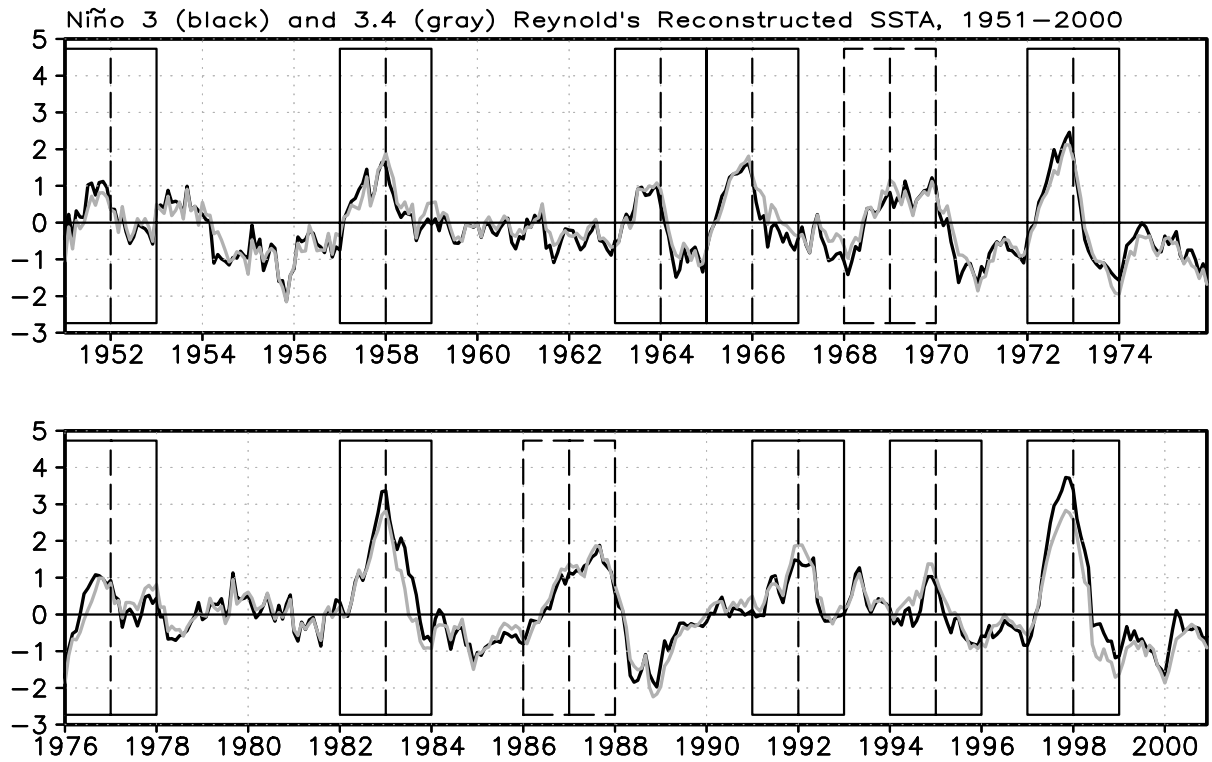

Fig. 5. Time series of monthly mean Niño 3 (black) and Niño 3.4 (gray) sea surface temperature anomalies from January 1951 to December 2000. The data used are from Reynold's reconstructed SST (Reynolds and Smith, 1994). Anomalies are departures from 1951-2000 climatology. Solid boxes outline the 10 El Niño cases used in the composite. Two dashed boxes indicate two El Niño events that are not selected.

veloping, mature, and decay phases of the composite El Niño event, respectively. In Fig. 7, we present monsoon anomalies in five consecutive seasons, i.e. $\operatorname{JJA}(0), \quad \operatorname{SON}(0), \quad \mathrm{D}(0) / \mathrm{JF}(1)$, $\operatorname{MAM}(1)$, and JJA(1). This composite scenario takes into account the season-dependent and ENSO phase-dependent characteristics of the AAM anomalies and is suitable for delineating the linkage and differences between Indian and East Asian sectors.

During the summer of El Niño development, the anomalous low-level circulation is characterized by an elongated anticyclonic ridge extending from the maritime continent to the peninsula of India (implying a moderate weak Indian summer monsoon) (Fig. 7a). On the other hand, to the north of the ridge, anomalous westerlies enhance the WNP monsoon trough and convection (Fig. $7 \mathrm{a})$. Thus the observed frequency of tropical storm formation in the southeast quadrant of the tropical WNP $\left(5-17^{\circ} \mathrm{N}, 140-170^{\circ} \mathrm{E}\right)$ drastically increases (Chen et al., 1998; Wang and Chan, 2002).

During the fall of an El Niño developing year, the southeast Indian Ocean anticyclone, which originated southwest of Sumatra in the previous summer, grows rapidly, leading to a giant anticyclonic ridge dominating the Indian Ocean with an anticyclone center located at $\left(10^{\circ} \mathrm{S}, 90^{\circ} \mathrm{E}\right)$ and a tilted ridge extending from western Australia all the way to Arabian Sea (Fig. 7b). Intense easterly anomalies develop along the equatorial Indian Ocean; convection is suppressed in the eastern Indian Ocean while enhanced in the western Indian Ocean with the most suppressed convection located slightly to the eastward and equatorward of the anticyclone center. Comparison with climatology, Fig. $7 \mathrm{~b}$ indicates that the monsoon rainfall and circulation of the entire A-AM system is severely reduced. Thus, the strongest ENSO impacts on the Indian sector occur normally in the fall of an ENSO developing year.

During the mature phase of El Niño, D(0)/ $\mathrm{JF}(1)$, the low-level circulation anomalies are controlled by two subtropical anticyclonic anomalies located in the southern Indian Ocean (SIO) and WNP, respectively (Fig. 7c). The former is a result of the weakening and eastward retreat of the SIO anticyclone previously established in fall, while the latter results from the amplification and east- 

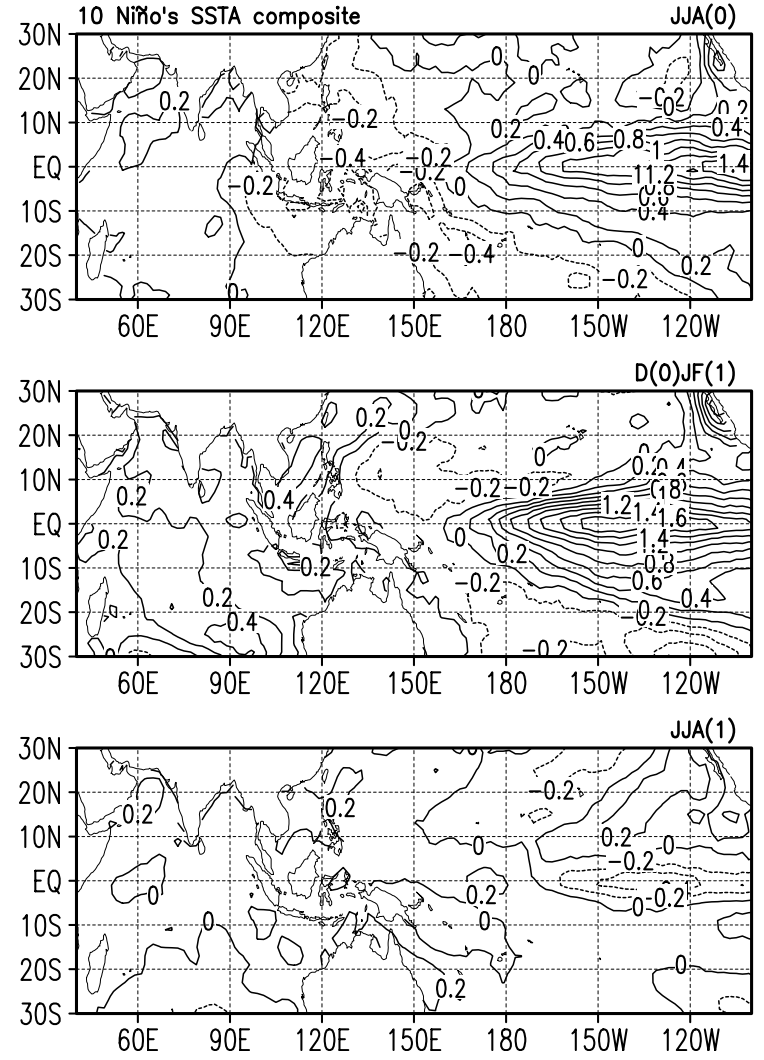

Fig. 6. Composite seasonal mean SST anomalies for selected 10 El Niño episodes: (a) JJA(0), (b) $\mathrm{D}(0) / \mathrm{JF}(1)$, and (c) JJA(1), where 0 denotes the year in which El Niño develops and 1 as the year El Niño decays. The data used are from Reynold's reconstructed SST (Reynolds and Smith, 1994).

ward migration of the Philippine anticyclone generated in the previous fall. Compared with climatology (Fig. 4), both the East Asian winter monsoon and the Australian summer monsoon are considerably weakened. However, Arabian Sea winter monsoon is enhanced.

During $\operatorname{MAM}(1)$ and JJA(1), the strongest monsoon anomalies are found in the WNP and East Asia (Fig. 7d,e). A salient feature is the persistence of the Philippine Sea anticyclone (Wang et al., 2000). The persistence of the Philippine Sea anticyclone affects the subtropical high and provides a prolonged impact on Meiyu/Baiu in $\mathrm{JJ}(1)$ when the El Niño disappears. By JJA(1), subsidence controls the Philippine Sea and Southeast Asia, leading to deficient summer monsoon rainfall there. This agrees with results derived from the previous studies, i.e. the WNP rainfall decreases (Wang et al., 2000) while the Meiyu/Baiu is inclined to increase (Fu and Teng, 1988; Chen et al., 1992; Shen and Lau, 1995; Lau and Weng, 2001).

How different are the impacts of El Niño on the monsoons over the Arabian Sea and South China Sea? In the summer of an El Niño developing year, JJA(0), the southwesterly monsoon over the Arabian Sea weakens, while that over the South China Sea strengthens (Fig. 7). However, during JJA(1), the southwesterly in both Arabian and the South China Seas weakens (Fig. 7e). In boreal winter, the El Niño-induced anomalous winds strongly offset mean northeasterly monsoons over the South China Sea, while reinforcing the northeasterly monsoon over the Arabian Sea (Fig. 7c).

In order to quantitatively measure the impacts of El Niño, we selected two regions, $\left(45-65^{\circ} \mathrm{E}\right.$, $\left.0-15^{\circ} \mathrm{N}\right)$ and $\left(105-120^{\circ} \mathrm{E}, 5-20^{\circ} \mathrm{N}\right)$, representing western Arabian Sea and South China Sea, respectively. The El Niño-induced composite anomaly winds were then projected onto the local summer (or winter) mean climatological wind vectors. The resulting difference, normalized by the climatological wind speed, denotes fractional changes of the annual cycle winds. Calculations were performed for each grid and then area averaged over the western Arabian Sea and South China Sea.

The results show that in $\operatorname{JJA}(0)$ and $\operatorname{JJA}(1)$, the composite El Niño anomalies reduce Arabian Sea monsoon by about $1.9 \%$ and $0.9 \%$, respectively, which is insignificant. In the extreme events, the reduction of summer monsoon can reach about $11 \%$ in JJA(0) (1972) and 7\% in JJA(1) (1966). On the other hand, the composite El Niño anomalies account for, on average, $10 \%$ of increase in $\operatorname{JJA}(0)$ and $9 \%$ of decrease in $\operatorname{JJA}(1)$ in the South China Sea summer monsoon. In the extreme El Niño events, the South China Sea monsoon was enhanced by $27 \%$ in JJA of 1972 and reduced by $37 \%$ in JJA of 1998. As such, El Niño may considerably alter the strength of the South China Sea summer monsoon.

How is the Australian monsoon variability related to the Asian monsoon variation on interan- 

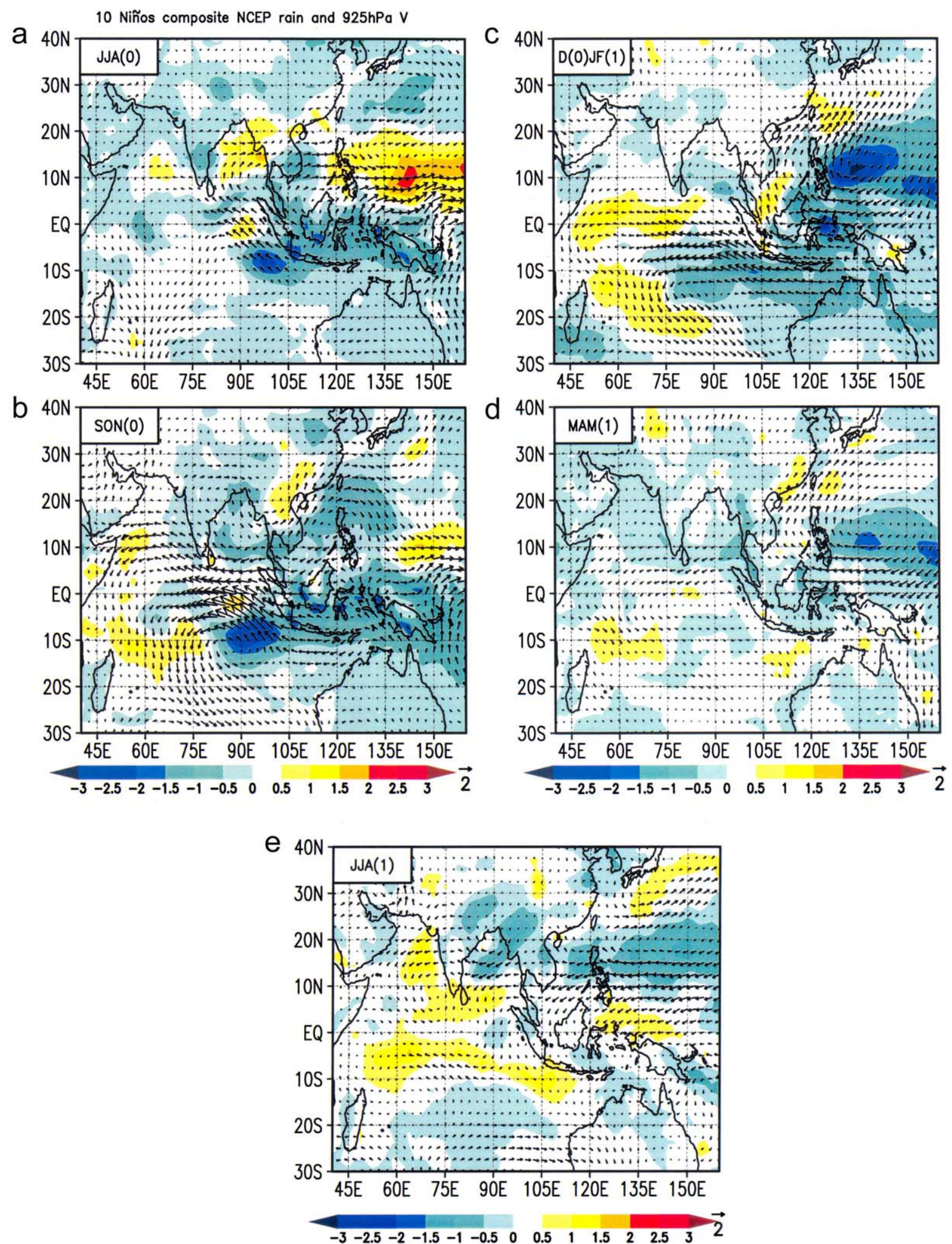


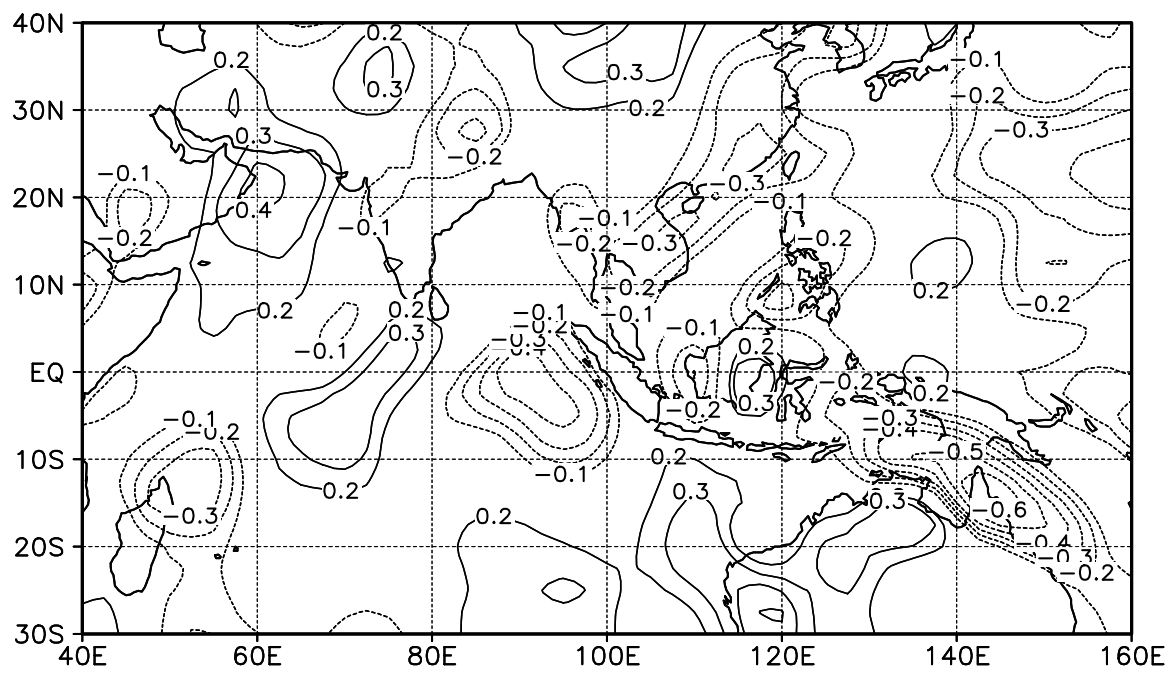

Fig. 8. Correlation map of seasonal (DJF) mean meridional wind anomalies with reference to the Australian summer monsoon (DJF) index that is defined by the zonal wind anomalies averaged over the region $\left(2.5-12.5^{\circ} \mathrm{S}, 120-150^{\circ} \mathrm{E}\right)$. The correlation coefficients are computed for the period of 1951-2000.

nual timescales? To address this question, we define, following the idea of McBride et al. (1995), an Australian monsoon index by using the 925 $\mathrm{hPa}$ zonal winds averaged over the region $(2.5-$ $\left.12.5^{\circ} \mathrm{S}, 120-150^{\circ} \mathrm{E}\right)$ where the annual reversal of winds is largest (Figs. 1 and 4). Fig. 8 shows a correlation map of the anomalous meridional winds with reference to the Australian summer monsoon index for the period of 1951-2000 (ensemble size 50). The enhanced Australian summer monsoon is highly correlated with the strength of the northerly winds associated with the East Asian winter monsoon. This connection is realized through the cross-equatorial flows in three channels located over the maritime continent: west of Sumatra, in between Sumatra and Borneo, and south of New Guinea. These cross-equatorial flows are essentially the same as seen on the annual timescale (Fig. 4). Fig. 8 also indicates no connection exists between Indian winter northeasterly monsoon and Australian summer westerly monsoon.

\section{Discussion: causes of the differences between the two A-AM subsystems}

\subsection{Annual cycle: geographic and orbital forcing}

The effects of the land-sea configuration and topography are fundamental in understanding the differences in the monsoon annual cycle between the Indian and the East Asian sectors.

Over Indian sector, the Asian landmass is located in the Northern Hemisphere (NH) while ocean occupies the Southern Hemisphere ( $\mathrm{SH})$. The land-ocean distribution is opposite over the East Asian sector: the landmass is in the $\mathrm{SH}$ while the ocean in the north. In addition, the Tibetan Plateau is located to the north of the Indian sector but to the west of the East Asian sector; the equatorial region of the Indian sector is occupied by deep ocean, while the equatorial region of the East Asian sector is occupied by the Indonesian archipelago and shallow continental shelves; the Indian Ocean is bounded by land in both the west

Fig. 7. Seasonal mean precipitation rate (mm/day, contour) and $925 \mathrm{hPa}$ wind anomalies composite for the 10 selected El Niño episodes shown in Fig. 6: (a) JJA (0), (b) SON(0), (c) D(0)/JF(1), (d) MAM(1), and (e) JJA(1), where year 0 denotes the year in which El Niño develops and 1 as the year El Niño decays. The data used are derived from NCEP/NCAR reanalysis (1951-2000) (Kalnay et al., 1996). 
and east, while the ocean in the East Asian sector is open to the east. These contrasts in geographic distribution of land and ocean as well as the complex topography results in remarkable differences in the thermal forcing for the two monsoon subsystems.

During boreal summer, the monsoon over the Indian sector is extremely powerful, because the meridionally differential solar radiation heating is reinforced by the strong north-south thermal contrast between the heated Asian land and cold SIO. In addition, the thermal effects of the elevated Tibetan Plateau heat source further strengthen this north-south thermal contrast. Thus, the extremely large north-south thermal contrast during boreal summer results in the strong Somalia jet and powerful Indian summer monsoon. Over the East Asian sector, the summer monsoon is driven by both the north-south thermal contrast between cold Australian land and warmer WNP and the east-west thermal contrast between the heated East Asian landmass and relatively colder Pacific Ocean. This directionally 'orthogonal' forcing results in a weaker summer monsoon with a tilt of the monsoon trough from the northern South China Sea to $\left(5^{\circ} \mathrm{N}, 160^{\circ} \mathrm{E}\right)$. However, because of the east-west thermal contrast, a giant North Pacific subtropical ridge develops which separates (but also couples) the subtropical rain belt and tropical rain belt, forming a coupled tropical and subtropical monsoon system with a large meridional extent. The land-ocean distribution in the East Asian sector renders the WNP monsoon more constrained by the ocean thermal inertia. Thus, both the peak rainy season and fall transition are about one-two months later than their counterparts in the Indian sector.

During northern winter, the monsoon over the East Asian sector is extremely powerful because of the contrast between the cold extratropical Asian landmass and the relatively warm North Pacific Ocean. The heated Australian land in the $\mathrm{SH}$ and colder ocean in the NH generate low-level cross-equatorial flows through the southern South China Sea. The monsoon in the Indian sector is moderate because of absence of heated land in the $\mathrm{SH}$ and because of the blocking of cold Siberian air by the Tibetan Plateau. The Australian sum- mer monsoon westerlies are intimately linked to the East Asian winter monsoon but not the winter monsoon from northern India Ocean (Fig. 4).

The above analysis suggests that the extreme phase of the monsoon annual cycle is a response to the solar radiation forcing and is primarily determined by land-ocean configuration and topography. Therefore, the annual variability of the strength of monsoon is primarily determined by changes in the solar and geographic forcing.

\subsection{Interannual variation: local monsoon-ocean interaction and El Niño forcing}

The way by which ENSO affects the A-AM has been considered primarily through changes in the Walker circulation (e.g. Ju and Slingo, 1995). We argue that in addition to the direct remote forcing, local monsoon-ocean interactions play a critical role in accounting for the different interannual variation in the two subsystems: the Indian and East Asian sectors. Here we present evidence to show the importance of local monsoon-ocean interaction.

In the Indian sector, the ENSO-related anomalies are stronger in boreal fall than in boreal winter, but the remote ENSO forcing is strongest in the boreal winter when ENSO matures. This mismatch suggests that additional factors must be in play besides the remote ENSO forcing. One of them is the local monsoon-ocean interaction. During JJA(0), the remote ENSO forcing suppresses Indonesian convection, in particular the convection southwest of the Sumatra where climatological rainfall reaches maximum (Fig. 7a). The suppressed convection southwest of Sumatra excites westward-propagating Rossby waves (Gill, 1980). This causes descending motion and reinforces the low-level anticyclonic anomaly in the southeast Indian Ocean and the southeasterly wind along the southern coast of Sumatra as well as the equatorial easterly anomaly. This, in turn, induces anomalous coastal and equatorial upwelling and excessive evaporation and entrainment cooling in the equatorial eastern and southeastern Indian Ocean (Fig. 6a). On the other hand, in the western Indian Ocean, the low-level circulation anomalies tend to be against climato- 
logical boreal summer monsoon, hence reducing the total wind speed. As a result, the equatorial western Indian Ocean, western Arabian Sea, and the southwestern subtropical Indian Ocean become warmer than normal (Fig. 6a). This is due both to suppression of the coastal and equatorial upwelling and evaporation cooling (over the Arabian Sea and west equatorial Indian Ocean), and to increased solar irradiance and suppressed evaporation cooling (over the subtropical southwestern Indian Ocean). The resultant SST anomaly pattern, referred to as the Indian Ocean Dipole mode or zonal mode (Saji et al., 1999; Webster et al., 1998), would further enhance the SIO anomalous anticyclone and associated equatorial easterly anomalies and Sumatra cross-equatorial flows. The above-described positive feedback depends on boreal summer monsoon background flow and is reversed quickly once the fall monsoon transition occurs after November. Therefore, the positive feedback-induced Indian Ocean anomaly pattern reaches maximum in boreal fall. It is the local Indian monsoon-ocean interaction that remarkably amplifies Indian monsoon anomalies in boreal fall (Fig. 7b).

In the East Asian sector, the El Niño weakens northern winter monsoon and the Australian summer monsoon (Fig. 7c). Pronounced anticyclonic monsoon anomalies occur over the Philippine Sea in MAM(1) and JJA(1) after the mature phase of ENSO when the remote forcing in the eastern Pacific decays rapidly (Fig. 6c). This fact implies that the Philippine Sea anticyclonic anomalies cannot be attributed simply to the remote forcing from the El Niño; rather, other processes must play a critical role in maintaining the Philippine Sea anticyclonic anomalies. Given the chaotic nature of atmospheric motion and the decaying remote forcing by El Niño, what mechanisms sustain the anomalous WNP subtropical anticyclonic anomaly from mature phase to ensuing summer? Wang et al. (2000) have attributed the development and persistence of the WNP anticyclonic anomaly to a positive thermodynamic feedback between atmospheric Rossby waves and the underlying warm-pool ocean. The increased total wind speed east of the anomalous anticyclone center cools the ocean surface due to excessive evaporation and entrainment. The cooling, in turn, suppresses convection and reduces latent heat release, which excites descending atmospheric Rossby waves that propagate westward and reinforce the WNP anomalous anticyclone.

In summary, the Indian monsoon weakening reaches peak phase in the fall of El Niño developing year and primarily over the SIO due to rapid intensification of the anomalous subtropical anticyclone over the SIO. On the other hand, the weakening monsoon over the WNP is prominent in the spring and summer during the decay of $\mathrm{El}$ Niño due to rapid intensification and maintenance of the anomalous subtropical anticyclone over the WNP. This difference in the Indian and East Asian sectors is due to monsoon-ocean interaction regulated by the local mean background seasonal cycle and their respective geographic locations relative to El Niño forcing. Thus, the monsoon-ocean interaction is critical to account for the differences in the interannual variations of the Indian and East Asian summer monsoons.

\section{Conclusion and discussion}

The low-level monsoon flows over the Arabian Sea and South China Sea are meaningful indicators of the strength for the Indian and East Asian summer monsoon, respectively. The sediments recorded in these two monsoon regions provide valuable information about the monsoon variability on geologic timescales. To facilitate interpretation of the results revealed by paleoclimatic records, we attempted to explore the differences between the 'internal' and 'external' forcing mechanisms of the monsoon system. This objective is achieved by contrasting the behavior of the two monsoon regions: the monsoon over the Indian sector (40$105^{\circ} \mathrm{E}$ ) and the monsoon over the East Asian sector $\left(105-160^{\circ} \mathrm{E}\right)$. These two monsoon regions have different land-ocean configurations. Their annual cycle and interannual variability are expected to be quite dissimilar. Understanding the dissimilar behavior in the annual cycle and interannual variability may help to understand the effects of the external vs. internal forcing of the monsoon system at longer time scales. 
The seasonal cycle differs in the two sectors of the A-AM system. The peak of the summer monsoon occurs in June-July in Indian sector but in July-August in the East Asian sector. The Indian summer monsoon consists of a single tropical monsoon system (Indian trough, equatorial gyre with Somalia jet, and Mascarene High), while the summer monsoon in the East Asian sector consists of a coupled tropical monsoon system (WNP trough, cross-equatorial flows and Australian High) and a subtropical monsoon system (WNP subtropical high and the East Asian subtropical monsoon front). While the summer monsoon is stronger in the Indian sector, the boreal winter monsoon is stronger in the WNP sector. The Australian summer monsoon is more closely coupled with powerful East Asian winter monsoon; and the Australian winter monsoon tends to be coupled with the WNP summer monsoon. These differences result arguably from the atmospheric response to differing land-ocean distribution and topography (geographic forcing) and the annual variation of the solar radiation as elaborated in Section 5.1.

On the interannual timescale, the variability in the Indian and East Asian sectors strongly depends on phases of ENSO. In the summer of an El Niño developing year, an anomalous anticyclone extends from the maritime continent to the southern tip of India, which increases the WNP monsoon westerly but weakens the Indian summer monsoon. In the mature phase of an El Niño, two anomalous anticyclones located over the SIO and WNP, respectively, dominate the AAM anomalies. These suppress the East Asian winter monsoon and Australian summer monsoon simultaneously. During the boreal spring and early summer after the El Niño mature phase, the anomalies are primarily found in the WNP and East Asia. The associated anomalous anticyclone is over the Philippine Sea, suppressing local convection while enhancing rainfall over the East Asian subtropical front. Thus, from the development to decay phase of El Niño, the variability center of the A-AM anomalies shifts from the Indian to East Asian sector. Note that, Meehl (1987) and others pointed out that a strong (weak) Indian summer monsoon is followed by a strong (weak) Australian summer monsoon. This is due to the eastward shift of the A-AM anomalies from the developing to mature phase of ENSO, which has to do with the phase locking of ENSO to the annual cycle. The phase locking of El Niño/La Niña peaks to boreal winter is one of the most robust features of ENSO cycle. It is primarily due to the seasonally varying basic state in the Pacific Ocean (Tziperman et al., 1998; An and Wang, 2001).

The internal factors that affect the strength of A-AM include not only remote forcing from ENSO but also the monsoon and warm ocean interaction. The strongest Indian monsoon anomalies occur during the fall of an El Niño developing year, while the strongest East Asian strongest anomalies occur in the spring after the El Niño year. These differences are attributed to: (1) the manner in which the regions are affected by remote forcing of the A-AM circulation, and (2) the ENSO-induced local monsoon-ocean interaction that substantially modifies direct ENSO impacts as discussed in Section 5.2.

The factors that control monsoon intensity (the amplitude of the annual reversal of the surface winds and/or the contrasting precipitation rate between wet summer and dry winter) may be classified in two groups: the forcing external to the coupled atmosphere-ocean-land system (geographic and solar orbital forcing) and the forcing internal to the coupled climate system, such as (remote) ENSO forcing, local monsoon-ocean interaction, land-atmosphere interaction, and extratropical influences (ice or snow cover). The mechanisms operating on the annual and interannual timescales are dominated, respectively, by the external and internal forcing. The differences between the Indian and East Asian monsoons is essentially determined by the relative strengths of the external vs. internal forcing. The factors that determine the intensity of the monsoonal annual cycle (the ocean-land configuration and topography and annual cycle of solar radiation) share common features with the paleo-monsoon variability caused by geographic/orbital forcing. The understanding gained from the aforementioned investigation may shed light on the mechanisms of monsoon variability that operate differ- 
ently on the short-term (interannual to interdecadal) and geological timescales.

The variability associated with ENSO (or the thermal conditions in the Pacific) has a moderate impact on the strength of the Arabian Sea summer monsoon (on average, it weakens by about $1-2 \%$ ), whereas it can substantially modify the strength of the South China Sea summer monsoon: by about $10 \%$ on average and about $40 \%$ in individual strong events. The latter suggests that a large change in the Pacific thermal conditions (disappearance of $\mathrm{El} \mathrm{Niño,} \mathrm{for} \mathrm{instance)} \mathrm{could}$ cause considerable changes of the amplitude of the East Asian monsoon. This difference may have significant implications for interpreting the paleo-monsoon records, which are used to deduce the geologic evolution of the Indian and East Asian monsoon.

The phase of the summer-monsoon-influenced pollen records off northern Australia match exactly the summer-monsoon phase measured in cores from the Indian Ocean (Clemens and Kershaw, pers. commun.). How to interpret this linkage on orbital timescale? Does the in-phase relationship between the Indian and the Australian monsoons on the orbital timescale share common mechanism(s) with that on the interannual timescale? Our results suggest that although the inphase relationship occurs both on orbital and interannual timescales, the mechanisms that establish these phase relationships are not necessarily the same. The quasi-in-phase relationship on the interannual timescale results primarily from the impacts of the remote ENSO. A typical warm event develops in boreal summer and matures toward the end of the year (as shown in Fig. 7). From boreal summer to winter, the remote Niño forcing continuously suppresses the maritime continent convection through changing Walker circulation. During Niño development, the suppressed maritime continent convection extends to the southern tip of Indian (Fig. 7a), causing weak Indian summer monsoon. During the ensuing austral summer, the same suppressed maritime continent convection weakens the Australian summer monsoon. Hence, on the interannual timescale the linkage between the Indian and Australian summer monsoons arises from the Niño forcing.
This mechanism can be responsible for the orbital-scale phase coupling between the Indian and Australian summer monsoons only if long-term ENSO variability dominates the sediment signal as suggested in Clement et al. (1999). In contrast, the results derived from the present study suggest that the coupling of the East Asian winter and Australian summer monsoon is a robust feature on the annual timescale. This linkage is established by geographic forcing. It is likely that this coupling would operate on orbital timescales. Understanding the extent to which ENSO versus orbital/geographic forcing is responsible for the phase coupling of Indian and Australian summer monsoons will require establishing the phase of the East Asian winter monsoon at orbital timescales as well as further modeling efforts using fully coupled GCM's.

\section{Acknowledgements}

B. Wang is in part supported by the NOAA Pacific program and the NSF Climate Dynamics program.

\section{References}

An, S.-I., Wang, B., 2001. Mechanisms of locking the El Niño/ La Niña mature phases to boreal winter. J. Clim. 14, 2164 2176

Chen, T.C., Weng, S.P., Yamazaki, N., Kiehne, S., 1998. Interannual variation in the tropical cyclone formation over the western North Pacific. Mon. Wea. Rev. 126, 1080-1090.

Chen, L.-X., Dong, M., Shao, Y.-N., 1992. The characteristics of interannual variations on the East Asian monsoon. J. Meteor. Soc. Jpn. 70, 397-421.

Clemens, S.C., Prell, W.L., 1990. Late Pleistocene variability of Arabian Sea summer monsoon winds and continental aridity: Eolian records from the lithogenic componenet of deep-sea sediments. Paleoceanography 5, 109-145.

Clemens, S.C., Prell, W.L., Murray, D.W., Shimmield, G., Weedon, G., 1991. Forcing mechanisms of the Indian Ocean monsoon. Nature 353, 720-725.

Clemens, S.C., Murray, D.W., Prell, W.L., 1996. Nonstationary phase of the PlioPleistocene Asian monsoon. Science 274, 943-948.

Clement, A.C., Seøger, R., Cane, M.A., 1999. Orbital controls on the El Niño/southern oscillation and the tropical climate. Palaeoceanography 14, 441-456. 
Davey, M.K., Huddleston, M., Sperber, K.R., Braconnot, P., Bryan, F., Chen, D., Colman, R.A., Cooper, C., Cubasch, U., Delecluse, P., DeWitt, D., Fairhead, L., Flato, G., Gordon, C., Hogan, T., Ji, M., Kimoto, M., Kitoh, A., Knutson, T.R., Latif, M., LeTreut, H., Li, T., Manabe, S., Mechoso, C.R., Meehl, G.A., Power, S.B., Roeckner, E., Terray, L., Vintzileos, A., Voss, R., Wang, B., Washington, W.M., Yoshikawa, I., Yu, J.Y., Yukimoto, S., Zebiak, S.E., 2002. STOIC: A study of coupled model climatology and variability in tropical ocean region. Clim. Dyn. 18, 403-420.

Fu, C., Teng X., 1988. The relationship between ENSO and climate anomaly in China during the summer time (in Chinese). Sci. Atmos. Sinica (Special issue), pp. 133-141.

Gill, A.E., 1980. Some simple solutions for heat-induced tropical circulation. Quart. J. R. Meteorol. Soc. 106, 447-462.

Ju, J., Slingo, J.M., 1995. The Asian summer monsoon and ENSO. Quart. J. R. Meteorol. Soc. 121, 113-168.

Kalnay, E., Kanamitsu, M., Kistler, R., Collins, W., Deaven, D., Gandin, L., Iredell, M., Saha, S., White, G., Woollen, J., Zhu, Y., Leetmaa, A., Reynolds, B., Chelliah, M., Ebisuzaki, W., Higgins, W., Janowiak, J., Mo, K.C., Ropelewski, C., Wang, J., Jenne, R., Joseph, D., 1996. The NCEP/ NCAR 40-year reanalysis project. Bull. Am. Meteorol. Soc. 77, 437-471.

Krishnamurti, T.N., 1971. Tropical east-west circulations during the northern summer. J. Atmos. Sci. 28, 1342-1347.

Krishnamurti, T.N., Bhalme, H.N., 1976. Oscillations of a monsoon system. Part I: Observational aspects. J. Atmos. Sci. 33, 1937-1954.

Krishnamurti, T.N., Surge, N., Manobianco, J., 1985. Annual cycle of the monsoon over the global tropics. WMO world climate research programme publications Ser. 4, WMO TD65, Part IV-I-IV-21.

Kumar, K.K., Rajagopalan, B., Cane, M.A., 1999. On the weakening relationship between Indian monsoon and ENSO. Science 284, 2156-2159.

Kutzbach, J.E., Guetter, P.J., 1984. The sensitivity of monsoon climates to orbital parameter changes for 9000 years B.P.: Experiments with the NCAR GCM. In: Berger, A., Imbrie, J., Hays, J., Kukla, G., Sultzman, B. (Eds.), Milankovitch and Climate: Understanding the Response to Astronomical Forcing. Reidel, Dordrecht, pp. 801-820.

Lau, K.-M., Weng, H., 2001. Coherent modes of global SST and summer rainfall over China: An assessment of the regional impacts of the 1997-1998 El Niño. J. Clim. 14, 1294 1308.

Latif, M., Sperber, K., Arblaster, J., Braconnot, P., Chen, D., Colman, A., Cubasch, U., Cooper, C., Delecluse, P., Dewitt, D., Fairhead, L., Flato, G., Hogan, T., Ji, M., Kimoto, M., Kitoh, A., Knutson, T., LeTreut, H., Li, T., Manabe, S., Marti, O., Mechoso, C., Meehl, G., Power, S., Roeckner, E., Sirven, J., Terray, L., Vintzileos, A., Voß, R., Wang, B., Washington, W., Yoshikawa, I., Yu, J., Zebiak, S., 2001. ENSIP: the El Niño simulation intercomparison project. Clim. Dyn. 18, 255-276.

McBride, J.L., Davidson, N.E., Puri, K., Tyrell, G.C., 1995. The flow during TOGA COARE as diagnosed by the
BMRC tropical analysis and prediction system. Mon. Wea. Rev. 123, 717-736.

Meehl, G.A., 1987. The annual cycle and interannual variability in the tropical Pacific and Indian Ocean region. Mon. Wea. Rev. 115, 27-50.

Meehl, G.A., Boer, G.J., Covey, C., Latif, M., Stouffer, R.J., 2000. The coupled model intercomparison project (CMIP). Bull. Am. Meteorol. Soc. 81, 313-318.

Overpeck, J.T., Trumbore, S., Prell, W.L., 1996. The southwest Indian monsoon over the last 18,000 years. Clim. Dyn. 12, 213-225.

Prell, W.L., Murray, D.W., Clemens, S.C., Anderson, D.M., 1992. Evolution and variability of the Indian Ocean summer monsoon: Evidence from the western Arabian Sea drilling program. In: Duncan, R.A., et al. (Ed.), The Indian Ocean: A Synthesis of Results from the Ocean Drilling Program. Am. Geophys. Union, Washington, DC, pp. 447-469.

Ramage, C., 1971. Monsoon meteorology. International Geophysics Series Vol. 15. Academic Press, San Diego.

Reynolds, R.W., Smith, T.M., 1994. Improved global sea surface temperature analyses using optimum interpolation. J. Clim. 7, 929-948.

Saji, N.H., Goswami, B.N., Vinayachandran, P.N., Yamagata, T., 1999. A dipole mode in the tropical Indian Ocean. Nature 401, 360-363.

Schulz, H., von Rad, U., Erienkeuser, H., 1998. Correlation between Arabian Sea and Greenland climate oscillations of the past 110,000 years. Nature 393, 54-57.

Shen, S., Lau, K.M., 1995. Biennial oscillation associated with the East Asian summer monsoon and tropical sea surface temperatures. J. Meteorol. Soc. Jpn. 73, 105-124.

Shimmield, G.B., Mowbray, S.R., Weedon, G.P., 1990. A 350 ka history of the Indian Southwest Monsoon - evidence from deep-sea cores, northwest Arabian Sea. Trans. R. Soc. Edinb. 81, 289-299.

Sirocko, F., 1991. Deep-sea sediments of the Arabian Sea: A paleoclimatic record of the southwest-Asain summer monsoon. Geol. Rundsch. 80, 557-566.

Tao, S., Chen, L., 1987. A review of recent research on the East Asian summer monsoon in China. In: Chang, C.P., Krisnamurti, T.N. (Eds.), Monsoon Meteorology. Oxford University Press, Oxford, pp. 60-92.

Trenberth, K.E., Stepaniak, D.P., Caron, J.M., 2000. The global monsoon as seen through the divergent atmospheric circulation. J. Clim. 13, 3969-3993.

Tziperman, E.L., Cane, M.A., Zebiak, S.E., Xue, Y., Blumenthal, B., 1998. Locking El Nino's peak time to the end of the calendar yearin the delayed oscillator picture of ENSO. J. Clim. 11, 2191-2199.

Wang, B., 1994. Climate regimes of the tropical convection and rainfall. J. Clim. 7, 1109-1118.

Wang, B., Lin, H., 2002. Rainy season of the Asian-Pacific summer monsoon. J. Clim. 15, 386-398.

Wang, B., Chan, J.C.L., 2002. How Strong ENSO Events affect tropical storm activity over the western North Pacific. J. Clim. 15, 1643-1658.

Wang, B., Xu, X., 1997. Northern Hemisphere summer mon- 
soon singularities and climatological intraseasonal oscillation. J. Climatol. 10, 1071-1085.

Wang, B., Wu, R., Fu, X., 2000. Pacific-East Asian teleconnection: How does ENSO affect East Asian climate? J. Clim. 13, 1517-1536.

Wang, B., Wu, R., Lau, K.M., 2001. Interannual variability of Asian summer monsoon: Contrasts between the Indian and Western North Pacific-East Asian monsoons. J. Clim. 14, 4073-4090.

Wang, L., Sarnthein, M., Erlenkeuser, H., Grimalt, J., Grootes, P., Heilig, S., Ivanova, E., Kienast, M., Pelejero, C., Pflaumann, U., 1999. East Asian monsoon climate during the Late Pleistocene: High-resolution sediment records from the South China Sea. Mar. Geol. 156, 245-284.
Wang, P., 1999. Response of Western Pacific marginal seas to glacial cycles: Paleoceanographic and sedimentological features. Mar. Geol. 156, 5-40.

Webster, P.J., Magana, V.O., Palmer, T.N., Shukla, J., Tomas, R.A., Yanai, M., Yasunari, T., 1998. Monsoons: Processes, predictability, and the prospects for prediction. J. Geophys. Res. 103, 14451-14510.

Xie, P., Arkin, P.A., 1997. Global precipitation: A 17-year monthly analysis based on gauge observations, satellite estimates and numerical model outputs. Bull. Am. Meteorol. Soc. 78, 2539-2558. 